\title{
Die God van die hemel
}

\section{J P OBERHOLZER}

Die benaming "God van die hemel" vir Jahwe kom vir die eerste keer voor in Genesis 24:7 as wisselvorm vir "die God van die hemel en die God van die aarde" in Genesis 24:3. die Septuagint lees in albei gevalle "die God van die hemel en die God van die aarde". Baie geleerdes aanvaar dat die Septuagintvertalers vs 7 uitgebrei het om by vs 3 aan te pas, en dat die Massoretiese teks 'n stilistiese variasie vertoon (vgl van Selms, Genesis in P.O.T., p 38). Inderdaad is die Hebreeuse manuskripgetuienis eenstemmig ten gunste van die Massoretiese teks, met uitsondering van die Codex Severi, waarin vs 7 'éló$h \bar{e}$ haššămayim ontbreek en bloot yhwh gelees word. Omdat, soos ons later sal sien, die benaming "God van die hemel" juis in die tyd van die Septuagintvertaling wyer in omloop was, is dit nie waarskynlik dat die vertaler hier doelbewus sou kies vir die voller uitdrukking nie. Die teksgetuienis van die Septuagint bied hier dus 'n gewigtige alternatiewe lesing.

Daar is belangrike betekenisverskil tussen die twee uitdrukkings. "Die God van die hemel en die God van die aarde" oefen sy regering uit oor 'n universum wat by wyse van sy twee komponente aangedui word. "Die God van die hemel" oefen sy universele regering uit met die hemel as setel en uitgangspunt. "God as God van die hemel beheers, deurdat Hy oor die hemel regeer, van die hemel af die wêreld" (Traub, TWNT, kol 520).

"Die God van die hemel en die God van die aarde" het dus sy parallelle in benaminge soos "Heer van die hele aarde" (Jos 3:11, 13; Mig 4:13; Sag 4:14; 6:5; Ps 97:5), "Groot Koning oor die hele aarde" (Ps 47:3; 95:3), "Regeerder van die hele aarde" (Gen 18:25; Jes 33:2), terwyl "die God van die hemel" sy parallelle het in "Allerhoogste God" (Gen 14:18, 19, 20, 22; Num 24:16; Deut 32:8; II Sam 22:14; Jes 14:14; Ps 21 X), "God van die gode", (Deut 10:17; Ps 136:2), "Heer van die here", (Deut 10:17; Ps 136:3), 'èlohè mārōm (Mig 6:6), en miskien ook yhwh siebā'ot.

Terwyl ons dus wel parallelle kan aanwys vir die benamings wat in Genesis 24:3, 7 voorkom, en die betekenisinhoud van albei ooreenstem met wat ons origens in die ouer bronne oor Jahwe verneem, is dit vreemd dat die twee benaminge, as ons ons aan die Massoretiese teks hou, eers ná die ballingskap weer te voorskyn kom, en dan in betreklik oorvloedige mate. In die werk van die Kronis vind ons die benaming yhwh 'êlohhe haššāmayim in II Kronieke 36:23 (= Esra 1:2) en Nehemia 1:5, 'éläh šmayy $\bar{a}^{\prime}$ in Esra 5:11, (saam met $\left.w^{e c} a r^{c} \bar{a}^{\prime}\right)$ 12; $6: 9,10 ; 7: 12,21,23$. In later literatuur vind ons die benaming 'êt hašš- 
ämayim in Psalm 136:26, 'élōhē hašśămayim in Jona 1:9 en die Aramese 'ělāh s'emayy $\bar{a}$ ' in Daniël 2:18, 19, 37, 44. In Daniël kom bowendien ook nog voor mèlèk šemayyā' (4:34) en māré-'-š mayyā' (5:23).

Kontemporêr aan Esra-Nehemia is die voorkoms van die benaming yahu 'élāh semayyā' (27:15; 30:27), 'ělāh semayyā' (3:12; 31:2;

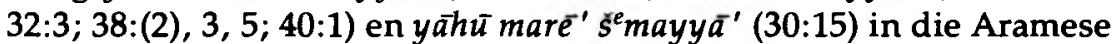
papiri van Elefantine. Tussen die tyd van Esra-Nehemia en die Elefantine-papiri aan die een kant en die tyd van die Daniëlboek aan die ander kant vind ons die benaming theos tou ouranou $(5: 8 ; 11: 17)$ en kurios ho theos tou ouranou $(6: 19)$ in Judit (gedateer saam met Rost 350-275), theos tou ouranou (10:11), kurios tou ouranou (10:13), basileus tou ouranou $(13: 7,11)$ in Tobit as ons Vaticanus en Alexandrinus volg (Tobit 200 v C). Ná die tyd van Daniël vind ons theos tou ouranou in I Makkabeërs 3:18 (103-63 v C) volgens Sinaiticus, basileus tou ouranou in 1 Esdras 4:46-58 (100-50 v C) en III Makkabeërs 2:2 (laaste derde van eerste eeu $v(C)$.

Die vergelyking van manuskripte toon egter' $n$ beduidende wisseling in die gebruik van hierdie benaminge. In sy plus teenoor Vaticanus en Alexandrinus het die Sinaiticusmanuskrip van Tobit theos tou ouranou in 7:13 en basileus tou ouranou in 1:18 en 13:16. Meer opvallend egter is dat waar Vaticanus en Alexandrinus bloot theos lees $(6: 17 ; 7: 12)$, Sinaiticus kurios tou ouranou het, of $(8: 15)$ theos tou ouranou, en in een geval (11:1) kurios tou ouranou kai tés gés, basileus tōn pantōn. Trouens, Sinaiticus stem net eenkeer (13:11) met Alexandrinus en Vaticanus ooreen, want basileus tou ouranou in 13:7 het nie 'n ekwivalent in Sinaiticus nie, en waar Alexandrinus en Vaticanus in 10:11 theos tou ouranou lees, lees Sinaiticus kurios tou ouranou en waar Alexandrinus en Vaticanus kurios tou ouranou lees in 10:13, het Sinaiticus bloot kurios. Die netto resultaat is dat Sinaiticus nege keer en Alexandrinus en Vaticanus net vier keer een van die drie benamings gebruik.

Ook tussen die Septuagintteks en Theodotion is daar beduidende verskille in gebruik van die benamings, dié keer in die boek Daniël. Theodotion stem met Mass. ooreen behalwe in 4:34 waar Theodotion mèlèk še mayy $\bar{a}^{\prime}$ weergee met hupsistos, en 5:23 mār $\bar{e}^{-'}-s^{e}$ mayy $\bar{a}^{\prime}$ met $k u-$ rios theos tou ouranou. LXX het 'n langer Daniëlteks as Mass. en Theodotion (voorkomste in 4:31,33a, 34) en gee bowendien 'illãya ' "Allerhoogste" in 4:17 (Mass. 4:14) weer met kurios tou ouranou. In 2:18, 19 word 'élāh s'mayyā' egter in LXX weergegee met kurius tou hupsistou en in 4:34 mèlek s $s^{e}$ mayya $\bar{a}^{\prime}$ met theos tou ouranou. In 9:3, 4 het Alexandrinus bowendien kurios ho theos tou ouranou teenoor Vaticanus en Sinaiticus se kurios ho theos. LXX-Daniël gebruik die benamings dus 7 keer, en as ons Alexandrinus volg, 9 keer teenoor Mass. se 6 en Theodotion se 5 keer.

Nog 'n interessante manuskripverskil is dié ten opsigte van I Mak- 
kabeërs 3:18 waar Alexandrinus en Vaticanus ouranos lees en Sinaiticus theos tou ouranou. Een gevolgtrekking wat ons seker kan maak uit dié verskille is dat in die eerste paar eeue $n C$ daar' $n$ bepaalde onsekerheid bestaan het oor die wenslikheid al dan nie om die betrokke benamings te gebruik. In die Nuwe Testament word dit net twee keer gebruik, en wel theos tou ouranou in Openbaring 11:13; 16:11. In die Vulgata is daar ' $n$ afwyking in Judit 6:19 (Vulg 6:15): Dominus Deus caeli et terrae.

Kyk ons nou verder na die wyse waarop die benamings gebruik word, vind ons die volgende:

In kommunikasie met vreemdes: Genesis 24:3, 7 (Eliëser die Demaskener), Esra 5:11, 12 (Persiese amptenare), Nehemia 2:20 (Sanballat e a), Papiri 27:15; 30:2, 15, 27; 31:2 (Persiese amptenare), Jona 1:9 (skeepsbemanning), Daniël 2:37, 44; 4:31 LXX (Nebukadnesar), 5:23 (Belsasar), Judit 11:17 (Holofernes), I Esdras 4:46 (Darius), (7 bronne) (17).

In die mond van vreemdes: II Kronieke 36:23; Esra 1:2 (Kores), 6:9, 10 (Darius), 7:12, 21, 23 (Artasasta), Papiri 32:3 (Bigwai), Judit 5:8 (Agior), Daniël 4:17, 33a LXX, (5 bronne) (12).

In himnes en gebede: Psalm 136:26; Nehemia 1:4, 5; 2:4; Daniël 2:18, 19; Judit 6:19; Tobit 8:15; 13:7, 11, 16; III Makkabeërs 2:2; I Esdras 4:58; Daniël 9:3, 4 LXX Alexandrinus (8 bronne) (13).

In vertellings en kommunikasie tussen Jode: Papiri 38:2, 3, 5; 40:1; Tobit 1:18; 6:17; 7:12, 13; 10:11, 13; 11:1; I Makkabeërs 3:18, (3 bronne) (12).

Met die uitsondering van vertellings en kommunikasie tussen Jode, wat beperk is tot nie-Bybelse materiaal, is die aanwending van die benamings dus eweredig versprei tussen die bronne. Gemeenskaplik is die himniese kwaliteit van die benamings, of dit nou in die kommunikasie met vreemdes is, deur vreemde konings en amptenare gebruik word of in himnes en gebede. In elk van die gevalle is God/Heer/Koning van die hemel 'n uitdrukking wat die hoë majesteit van Jahwe wil uitdruk, of dit nou om egte of diplomatieke redes is. Opvallend is dat die kunsmatige gebruik van die benamings, soos wanneer dit gelê word in die mond van Nebukadnesar, Kores of Agior, nie verskil van die werklike, praktiese gebruik in die amptelike dokumente in Esra en die Elefantine-papiri nie. Die Kronis en die skrywers van Judit en Daniël sluit hulle dus aan by bestaande gebruike.

Die feit dat die benamings in himniese of gebedetaal voorkom meer as in enige van die ander aanwendings, lei tot die gevolgtrekking dat dit die beginpunt is vir ' $n$ antwoord op die vraag waarom 
die benamings vir' $n$ tydperk van goed 500 jaar in onbruik was, en na 'n paar eeue van betreklik spaarsame gebruik, weer in onbruik geraak het. Dit is seker nie toevallig dat in die latere literatuur die majesteitsuitdrukkings in die benamings vir God vermenigvuldig nie, vgl 'ädōn Psalm 8:2, 10; 12:5, 114:7; 135:5; 147:5; Nehemia 3:5; 8:10; 10:30, 'ădōn kol-hā'-ārèș Psalm 97:5, 'ădōnē hä'ádōnīm Psalm 136:3, märē' malkin Daniël 2:47, mèlèk gâadol 'al-kol-hā'ārès Psalm 47:3; 95:3, mèlèk kol-hā'āreș Psalm 47:8, mèlèk rāb Psalm 48:3, nơrā' cal-kolhä'äreș Psalm 96:4, me'ód nacăletā cal-kol-hä'äreș Psalm 97:9, élōhē hã'èlohīm Psalm 136:2, 'êlöhìm haggādôt Nehemia 8:6, 'êt gädot Psalm 77:14; 95:3; Daniël 9:4; Nehemia 1:5; 9:32, 'êt 'étim Daniël 11:36, 'élāh 'élăhin Daniël 2:47, 'élāhā' cillā ăh Daniël 3:26, 5:18, 21, Kurios tou hupsistou Daniël LXX 2:18, 19, kurios tou megalou Daniël LXX 2:20, kurios tōn basileōn Daniël LXX 2:47, kurios tōn kuriōn Daniël LXX 4:34, theos ton theōn Daniël LXX 2:47; 4:34, basileus megas Judit 2:5 kurios pasés tés gés Judit 2:5, kurios pantokratōr Judit 16:6, 17, despotés Tobit 3:14 (Sin.) 8:17 Judit 5:20; 7:11, despotés tōn ouranōn kai tés gés Judit 9:12, despotés pasés ktiseōs III Makkabeërs 2:2. Hierdie tendens volg op die volkome geestelike oorwinning van Israel oor die afgodery tydens die ballingskap soos ons dit uitgedruk vind by Deuterojesaja. Die enigheid en onvergelyklikheid van die God van Israel is finaal gestel, en die krisis wat hom voor die ballingskap telkens voorgedoen het in die konfrontasie met die hoë gode van die Kanaänitiese, Aramese en Akkadiese wêreld, sou nie na die ballingskap herhaal word nie. Konfrontasie sou daar wel wees, veral in die tyd van die boek Daniël, maar dit het geskied met die verenigde weerstand van dié deel van die Jodedom waaruit die voorhande Bybelse en na-Bybelse literatuur voortgekom het. Dit is juis in hierdie literatuur waar die majesteitsuitdrukkings in die benamings vir die God van Israel wemel. Wat dit betref, het daar' $n$ vreeslose en gedetermineerde Israel uit die ballingskap gekom.

Hierdie godsdienshistoriese ontwikkeling hang saam met die aanvaarding van opperheerskappy oor die ONO deur die Perse. Of daar egter ' $n$ doelbewuste amptelike identifikasie tussen die verskillende hemelgode Baäl Samen, Hadad en Jahwe plaasgevind het omdat die Persiese heersers in die gedagte van die hemelgod 'n godskonsep gevind het wat by hulle eie godsdienstige idees gepas het en so' $n$ identifikasie bruikbaar gevind het vir hulle eenheidspolitiek, soos Albert Vincent dit wil (La Religion des Judeo-Araméens d'Elephantine, 1937, p $141 \mathrm{v}$ ), is te betwyfel. Dit is waar dat Esra 'n Persiese amptenaar was as "skrifgeleerde in die wet van die God van die hemel". (Esra $7: 12,21)$ maar tot dusver is geen aanduiding gevind dat daar vir godsdienssake van die dienaars van Baäl Samen en Hadad dergelike amptenare aan die Persiese hof was nie. Feit is dat net die Joodse godsdiens eksklusief van aard was ten opsigte van die identifikasie 
van hulle God met ander, of sy diens naas ander, en dat die dienaars van Baäl Samen en ander hoë gode steeds oopgestaan het vir sinkretisme. Nie die Perse nie, maar die Jode self is die outeurs van die benaming "God van die hemel" en sy variante.

Eissfeldt ( $B a^{c}$ alsamem und Jahwe, ZAW 57, 1939; Kleine Schriften II, 1963) wys daarop dat Baälsamēn in Israel vereer is telkens wanneer Israel met ander state noue politieke verbintenisse gehad het (KS p 192), waar sinkretisme dus diplomatieke gronde gehad het. Dit kan die rede wees waarom oor 'n baie lang tyd die term "God van die hemel" in Ou-Testamentiese geskrifte vermy is, want Baälsamēn dra wel enkele kere die benamings "God van die hemel" (Zakir ii $25 \mathrm{vgl}$ Philo van Byblos ouranou kurios Eisf. p 173), "koning" (Hatra 16:1, 2), 'ādōn (CIS i 7:5; 139:1h), $\mathrm{mr}^{\prime c} \mathrm{~lm}^{\prime}$ "heer van die wêreld" (CIS ii 3912:1, 3986:1), $m r^{\prime} k l$ "heer van alles" (CIS ii 3998 B:1). Die Baäldiens was, as ons uit na-eksiliese geskrifte moet oordeel, nie meer 'n bedreiging nie, en daarom kon majesteitsepitheta vir Jahwe wat vir'n lang tyd nie gebruik kon word nie, weer tevoorskyn gehaal word. 'n Ander moontlikheid is dat in Daniël dit die polemiese motief is wat lei tot die uitdruklike gebruik van die benamings vir Jahwe. Die vasstelling, oorspronklik deur Nestle (vgl Eissfeldt p 192), dat die "gruwel van verwoesting" (šiqqūss šomēn) wat deur Antiochus IV in die heiligdom opgestel is, ' $n$ vervorming van die naam Baäl Samen is, en dit hier nie om 'n Griekse god (Zeus Olympios volgens II Makkabeërs 6:2) gegaan het nie, verleen ' $n$ besondere agtergrond aan die gebruik van die terme God/Heer/Koning van die hemel in Daniël.

Ek kan ook nie Eissfeldt se opvatting, deels in aansluiting by Vincent, deel dat die Jode met die benamings "God van die hemel" of "God van hemel en aarde" aansluit by prediseringe vir Ahuramazda nie, want hoewel daar allerlei majesteitsuitdrukkings aan Ahuramazda se naam geknoop word, byvoorbeeld "grootste van die gode" (byvoorbeeld Persepolis H.1) en "'n Groot god is Ahuramazda, wat hierdie aarde geskape het, daardie hemel geskape het, die mense geskape het" (byvoorbeeld Xerxes D1 in Fr Spiegel, Die Altpersischen Keilinschriften 1862), word hy nooit "God van die hemel" genoem nie. Godsdienshistories sluit die titel "God van die hemel" aan by die Akkadiese (en Kanaänitiese) wẽreld, vgl Tallquist, Akkadische Götterepitheta (Anu, Enlil, Sin, Nannar, Adad, Marduk, Samas, Assur, Ninurta).

Vir die voorkoms van die benaming "God/Heer van die hemel" vir Jahwe in Elefantine bied Vincent die verklaring dat diê benamings saam met die Israeliete wat in die 7e eeu uit Betel na Elefantine verhuis het, gegaan het. Betel sou dan as gevolg van wat in Genesis 35 in verband met Jakob se droom vertel word, by uitstek die plek wees waar Jahwe vereer is onder die benaming "God van die hemel". Probleem is dat dié titel nêrens in die Ou Testament in verband met 
Betel gebruik word nie, en dat Vincent se hipotese onbewysbaar bly. Die ooreenkoms tussen die situasie van die Jode in Elefantine en dié van die Jode in ballingskap dui egter miskien op 'n ander antwoord. Albei was in direkte kontak met beoefenaars van vreemde kultusse, en albei het onder die opperheerskappy van 'n betreklik toegeneë Persiese regering gestaan. As reeds eeue voor die ballingskap die neiging bestaan het om teenoor vreemdes die eie God as hoogste en enigste God aan te dui, soos uit Genesis 24:3, 7 afgelei kan word, is dit natuurlik dat dit ook in albei hierdie situasies in die vreemde gebeur. Ten spyte van die sinkretisme in Elefantine, het die polemiese eksklusiwiteit ten opsigte van Jahwe ook daar nie verlore gegaan nie. 